\title{
THE EFFECTS OF TEMPERATURE AND MOISTURE STRESS CONTENT ON THE EXTENSIVE CULTIVATION OF THE OYSTER MUSHROOM
}

\author{
Vasil Popovych* Mykhailo Les** Taras Shuplat* Pavlo Bosak* \\ Mykhailo Fitak** and Nataliya Popovych*** \\ *Department of Ecological Safety, Lviv State University of Life Safety, \\ Lviv, Ukraine. \\ **Department Landscape Architecture, Garden Park Economy and \\ Urboecology, Ukrainian National Forestry University, Lviv, Ukraine. \\ ****Department of Administrative-Legal Disciplines, Lviv State University \\ of Internal Affairs, Lviv, Ukraine. \\ •Corresponding author e-mail: popovich2007@ukr.net
}

Received Date:23 September 2019, Accepted Date: 01 December 2019, Published Date: 26 December 2019

\section{ABSTRACT}

Oyster mushroom (Pleurotus ostreatus (Jacq. ex Fr.) P. Kumm.) is involved in the destruction of dead wood which is the main place of settlement of several living organisms. After humification, dead wood also becomes an important component of forest soils.

The purpose of the research is to study temperature and moisture conditions of extensive cultivation of oyster mushrooms on various wood substrates. To accomplish this goal, the following tasks were set: to determine the amount of effective stress temperatures and moisture content of substrates and their influence on the appearance of fruiting bodies of the oyster mushroom; to study the features of the extensive cultivation of oyster mushrooms on the tree stumps of cutover areas, in the hollows of broadleaved trees, using brushwood, on inoculated $\log$ sections in trenches, on log sections of dead dry trees. The oyster mushroom fruiting bodies collected in the suburban forest formed the basis of the experiment on the inoculation of different types of substrates. The inoculation of the log sections was carried with a relative air humidity of $85 \%$, the process of overgrowing lasted from 2 to 3 months. The edaphic-climatic factors of different types of space - closed and open - were taken into account.

The amount of effective temperatures necessary for the development of fruiting bodies has been determined. It was found that the intensive growth of the mushroom fruiting bodies begins after a sharp cooling (a drop in night temperatures to $4-8^{\circ} \mathrm{C}$ ), which causes a stressful state of the mushroom. The amount of the effective stress temperatures is $4.6^{\circ} \mathrm{C}$. Long-term phenological observations have revealed that the amount of the effective temperatures in the spring is $76.4^{\circ} \mathrm{C}$, and in the autumn $-59.4^{\circ} \mathrm{C}$. The duration of fruiting of oyster mushroom on $\log$ sections of hardwoods is 14 days in spring and 17 days in autumn longer than on softwoods blocks. It was found that the biomass of the fruiting bodies is directly dependent on 


\section{The effects of temperature and moisture stress}

the thickness of the log section, and, therefore, it is recommended to use log sections ranging from $35 \mathrm{~cm}$ to $50 \mathrm{~cm}$ in diameter and up to $30 \mathrm{~cm}$ in length.

Keywords: Cultivation, Extensive, Inoculation, Mushroom, Oyster.

\section{INTRODUCTION}

Oyster mushroom (Pleurotus ostreatus (Jacq. ex Fr.) Kumm.) is involved in the destruction of dead wood which is the main place of settlement of living organisms. After humification, dead wood also becomes an important component of forest soils; with its decomposition, especially favorable conditions for the development of topsoil and the renewal of woody species are formed (Popovych and Les, 2014). It is also essential for the accumulation of carbon and the protection of soil from erosion. In forests, about $15 \%$ of carbon is contained in dead wood. The 2005 European Forest Protection Conference (MCPFE) emphasized the importance of dead wood, an average stock of which (dead standing trees and wood debris) in Europe amounted to $10 \mathrm{~m}^{3} \mathrm{ha}^{-1}$ forest area (Pasternak and Yarotsky, 2010).Thus, it can be said that in Ukraine as well, it is necessary to introduce modern biotechnologies for utilization of wood waste. One of them is to use wood waste for cultivating mushrooms for food needs.

The environment, both biotic and abiotic, has a dramatic impact on tree damage by mycelium (Kucheryavyj et al., 2016). Among important abiotic factors are humidity, temperature, acidity level, chemical pollution of the atmosphere and soil, and of biotic - a species composition of flora and fauna (Kucheryavyj,1999; Pakhomova, 2014).Moisture deficiency contributes to tree drying out: there is a correlation between the increase in damage and periods of drought.The development of the pathogen is promoted by increased temperature and acidity of the soil (Černy, 1989; Pavlík, 2005; Piškur et al., 2011; Pavlik and Pavlik, 2013).

During a long evolution, plants got adapted to a certain change in temperature (Veretenikov, 1987). This applies, for example, to winter cereals which, for normal development, require a temperature of up to $2-20{ }^{\circ} \mathrm{C}$ for the period of 1 to 2 months. A similar phenomenon is also found in the development of the oyster mushroom whose fruiting bodies, according to many authors, appear after a sharp drop in the night temperature to 4 - 8 ${ }^{\circ} \mathrm{C}$. It is believed that a sharp drop in temperature causes stress, which gives an impetus to the active development and growth of the mushroom. The temperature that promotes the development of rhizomorph of the mushroom, as well as the fruiting bodies, is about $20 \mathrm{C}^{\circ}$ at PH 4 (Luthardt, 1968; Pakhomova, 2014).

All these peculiarities of the cultivation of oyster mushrooms on the stumps of cutover areas were taken into account in our study conducted in the summer and autumn of the 20152018 period on the hornbeam-oak-beech cutover areas of the Bryukhovychy forest district of Lviv region (Ukraine) (compartments 35-43) on the stumps of beech, hornbeam and birch trees left after the main felling.

The aim of the research is to study the temperature and moisture conditions for extensive cultivation of oyster mushrooms on different wood substrates.

To accomplish this goal, it was intended to solve the following tasks:

(1) To determine the amount of effective stress temperatures and moisture content of substrates and their influence on the appearance of oyster mushroom fruiting bodies.

(2) To study the peculiarities of extensive cultivation of oyster mushrooms: 
Popovych et al.

- on cutover areas of tree species.

- in hollows of broadleaved trees.

- with the use of brushwood.

- on inoculated log sections in trenches.

- on log sections of dead dry trees.

Mycelium-inoculation of stumps on the cutover areas was preceded by reconnaissance and phytopathological studies according to the methods (Bysko et al., 1983; Bulat, 2009).

\section{MATERIALS AND METHODS}

The distribution and occurrence of oyster mushrooms in the forests of Lviv Roztochya, Ukraine have been investigated. Material was selected to isolate a pure culture with the help of which mycelium was made which was used for oyster mushroom inoculation of logs of fresh (green) and moistened dead wood, as well as inoculation of stumps and brushwood on the cutover areas.

The isolated culture of oyster mushroom fruiting bodies collected in a suburban forest formed the basis of the experiment with inoculation of various types of substrates. To create and research the mycelium of the culture of oyster mushroom, the developed and well-formed fruiting bodies were selected which were delivered to the mycology laboratory within five hours. To activate growth before inoculating the substrate, the mycelium (mushroom spawn) was conditioned for 24 hours at room temperature and only then was sown in an amount of 5$7 \%$ of the substrate mass.

The strain is unknown because it is obtained by isolating a pure culture from fruiting bodies found in natural conditions. The inoculation of the $\log$ sections was carried out in the basement with a relative humidity of $85 \%$, the process of fouling lasted from 2 to 3 months. When using dry wood, it was soaked in water for a week. Cutting the logs into sections was carried out on the day of inoculation. The optimum diameter of a segment $30-40 \mathrm{~cm}$. The height of the segments was $30-35 \mathrm{~cm}$; an average of $150 \mathrm{~g}$ of mycelium was applied per segment.

To inoculate stumps on the cutover areas, the stumps of $40-70 \mathrm{~cm}$ in a felling-level diameter were chosen. In May-June, seed mycelium was applied to the sapwood part of the stump surface, with a 3-5 cm thick disc having been previously cut off it. After sowing, the disk was nailed with two nails to the block. The consumption rate of mycelium is $180-200 \mathrm{~g}$ per stump.

The pre-stress period, stress period, and post-stress period correspond to changes in daily ambient temperatures, where the inoculated blocks with oyster mushroom mycelium were placed. The research data obtained indicate the appearance of fruiting bodies after temperature stress, as it occurs in vivo. The yield of oyster mushroom was assessed by observation during the spring and autumn waves of fruiting, and stocks were determined by multiplying the areas of their growth by yield per unit area.

The study of the microclimate features in the experimental area with log sections, on which the oyster mushroom was grown, was carried out with the help of thermographs and hygrographs; the mass of oyster mushrooms during the study of yield was determined by weighing the cut-off fruiting bodies of the first fruiting wave. 
The effects of temperature and moisture stress

By the effective temperature is meant the difference between the temperature of the environment and the temperature threshold of organism development and the amount of effective temperatures $(X)$ is calculated by the formula (Kucheryavyj, 2010):

$$
\mathrm{X}=(\mathrm{T}-\mathrm{C}) \times \mathrm{t}
$$

Where: $\mathrm{T}-$ is the environmental temperature; $\mathrm{C}-$ is the temperature threshold of development; $\mathrm{t}-$ is the number of hours or days with a temperature exceeding the threshold of development.

\section{RESULTS AND DISSCUSSION}

Using meteorological data and our own microclimatic studies, we investigated the nature of the amount of effective temperaturesduring the period of a sharp drop in the daily stress temperatures and post-stress period of the development of the fruiting bodies in Table (1).

Table (1): Calendar of oyster mushroom development in pre-stress, stress- and post-stress periods (2016).

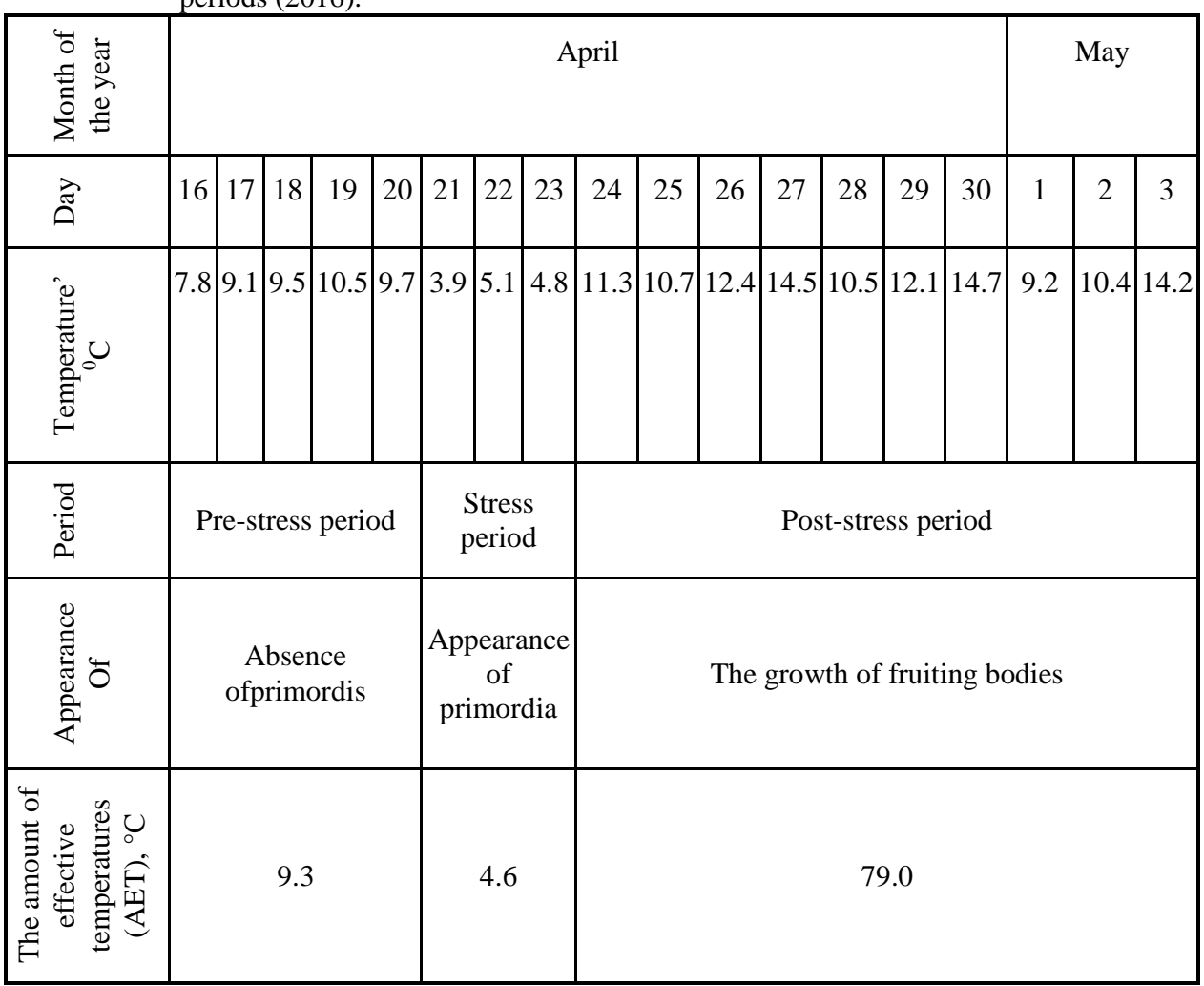

It is proved that a sharp drop in temperature causes stress, which gives impetus to the active development and growth of oyster mushrooms (Diag. 1). It was found that before the stress period, the night average temperature was $9.3 \mathrm{C}^{\circ}$ and at night of 21 April it dropped sharply to $3.9 \mathrm{C}^{\circ}$. The cooling lasted four days (until 24 April), after which primordis appeared on the aspen log sections; the growth of fruiting bodies continued until 3 May. 


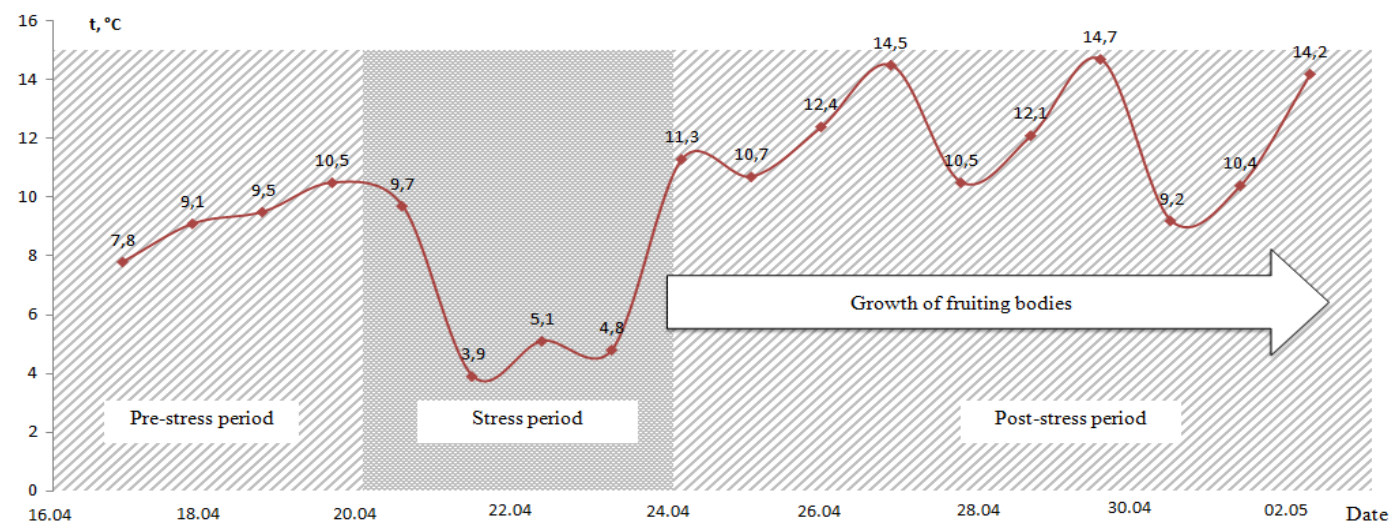

Diagram (1): Development of the oyster mushroom in pre-stress, stress, and post-stress periods.

At the end of fruiting, the raised temperature and reduced air humidity accelerated the process of completing the development of mushrooms. A similar course of temperature and oyster mushroom development was also observed in the autumn.

Here is the calculation of AET for the first autumn wave of fruiting, when the stress average daily temperature from 2 October to 5 October 2015 was $3.7 \mathrm{C}^{\circ}$. The primordis appeared on 7 October 2015 (the average daily temperature was $7.9 \mathrm{C}^{\circ}$. From this point on, the growth of fruiting bodies began and lasted for 28 days as the longest over the entire period of our investigations.

$$
\mathrm{AET}=(7.9-4.0) \times 28=113 \mathrm{C}^{\circ}
$$

Phenological three years' studies on the growth of oyster mushrooms $(2015,2016,2017)$ at the trial plots after overgrowing of log sections of eight species by mycelium confirmed the data of many authors (Bysko et al., 1982,1983),about the beginning of intensive growth of oyster mushroom fruiting bodies after stress caused by a sharp drop in temperatures (4-8 $\left.\mathrm{C}^{\circ}\right)$.We have calculated the amount of effective temperatures for the development of oyster mushrooms from the day of a sharp drop in temperature and the appearance of primordis presented in Table (2). 
The effects of temperature and moisture stress

Table (2): Amount of effective temperatures (AET) and the development of oyster mushrooms.

\begin{tabular}{|c|c|c|c|c|c|c|}
\hline \multirow[b]{3}{*}{$\begin{array}{l}\text { Years of } \\
\text { studies }\end{array}$} & \multicolumn{6}{|c|}{ Amount of effective temperatures } \\
\hline & \multicolumn{3}{|c|}{ Spring } & \multicolumn{3}{|c|}{ autumn } \\
\hline & $\begin{array}{c}\text { the } \\
\text { beginning } \\
\text { of the } \\
\text { season }\end{array}$ & $\begin{array}{l}\text { the end } \\
\text { of the } \\
\text { wave }\end{array}$ & $\begin{array}{c}\text { the duration } \\
\text { of the wave } \\
\text { /AET }\end{array}$ & $\begin{array}{c}\text { the } \\
\text { beginning of } \\
\text { the wave }\end{array}$ & $\begin{array}{l}\text { the end } \\
\text { of the } \\
\text { wave }\end{array}$ & $\begin{array}{c}\text { the duration } \\
\text { of the wave } \\
\text { /AET }\end{array}$ \\
\hline 2015 & 8.04 & 23.04 & $16 / 97.6$ & 1.10 & 15.11 & $16 / 65.6$ \\
\hline 2016 & 9.04 & 21.04 & $13 / 50.7$ & 1.11 & 14.11 & $14 / 65.8$ \\
\hline 2017 & 8.04 & 25.04 & $18 / 81.0$ & 14.10 & 26.10 & $13 / 46.8$ \\
\hline $\begin{array}{l}\text { Average } \\
\text { index }\end{array}$ & - & - & $16 / 76.4$ & - & - & $14 / 59 / 4$ \\
\hline
\end{tabular}

The considerable length of fruiting time is explained by the cool period during the development, when the average daily temperature rarely exceeded $15 \mathrm{C}^{\circ}$. On average, over three years, the spring and autumn AET is somewhat different: in the autumn, it is higher by $17 \mathrm{C}^{\circ}$.

We also carried out a AET calculation for the development of oyster mushrooms for two plots in Table (3): one is represented by log sections of hard wood broadleaved species Fagus sylvatica, and the second - by logs of soft wood broadleaved species Populus tremula which, as shown, differed in wood moisture content (absolute moisture content of Fagus sylvatica 119, Populus tremula - 205).

Table (3): The amount of effective temperatures (AET) and the development of oyster mushrooms on log sections of various tree species (2017).

\begin{tabular}{|c|c|c|c|c|c|c|}
\hline \multirow[b]{2}{*}{ Species name } & \multicolumn{3}{|c|}{ Spring } & \multicolumn{3}{|c|}{ Autumn } \\
\hline & $\begin{array}{l}\text { The } \\
\text { beginnin } \\
\mathrm{g} \text { of the } \\
\text { wave }\end{array}$ & $\begin{array}{c}\text { The end } \\
\text { of the } \\
\text { wave }\end{array}$ & $\begin{array}{c}\text { The } \\
\text { duration of } \\
\text { the wave / } \\
\text { AET }\end{array}$ & $\begin{array}{c}\text { the } \\
\text { beginning } \\
\text { of the wave }\end{array}$ & $\begin{array}{c}\text { The end } \\
\text { of the } \\
\text { wave }\end{array}$ & $\begin{array}{c}\text { The } \\
\text { duration of } \\
\text { the wave / } \\
\text { AET }\end{array}$ \\
\hline Fagus sylvatica & 9.04 & 30.04 & $22 / 143$ & 13.10 & 29.10 & $17 / 49.3$ \\
\hline Populus tremula & 6.04 & 23.04 & 18 / 594 & 15.10 & 26.10 & $12 / 45.6$ \\
\hline
\end{tabular}

It turned out that the duration of fruiting on beech log sections was longer than that of aspen by 4 days in spring and 5 days in autumn.

To study the development of the oyster mushroom fruiting body, aspen was chosen, where individuals with different cap sizes and weights develop in Table (4). 
Popovych et al.

Table (4): The weight of oyster mushroom fruiting bodies on the aspen log sections, $g$ (Autumn 2016).

\begin{tabular}{|c|c|c|c|}
\hline \multirow{2}{*}{$\begin{array}{l}\text { No. of the study } \\
\text { mushroom cap }\end{array}$} & \multicolumn{3}{|c|}{ Duration of growth, $\mathrm{h}$} \\
\hline & 48 & 120 & 216 \\
\hline $\begin{array}{l}\text { Study mushroom } \\
\text { No.1 }\end{array}$ & 3 & 12 & 76 \\
\hline $\begin{array}{l}\text { Study mushroom } \\
\text { No.2 }\end{array}$ & 2 & 11 & 70 \\
\hline $\begin{array}{c}\text { Study mushroom } \\
\text { No.3 }\end{array}$ & 3 & 13 & 78 \\
\hline $\begin{array}{c}\text { Study mushroom } \\
\text { No.4 }\end{array}$ & 2 & 10 & 66 \\
\hline $\begin{array}{l}\text { Study mushroom } \\
\text { No.5 }\end{array}$ & 3 & 9 & 63 \\
\hline $\begin{array}{c}\text { Study mushroom } \\
\text { No.6 }\end{array}$ & 3 & 12 & 78 \\
\hline $\begin{array}{c}\text { Study mushroom } \\
\text { No.7 } \\
\end{array}$ & 1 & 8 & 60 \\
\hline $\begin{array}{c}\text { Study mushroom } \\
\text { No.8 }\end{array}$ & 1 & 7 & 59 \\
\hline $\begin{array}{c}\text { Study mushroom } \\
\text { No.9 }\end{array}$ & 3 & 10 & 74 \\
\hline $\begin{array}{c}\text { Study mushroom } \\
\text { No.10 }\end{array}$ & 2 & 9 & 65 \\
\hline Average & 2.4 & 10.1 & 68.9 \\
\hline
\end{tabular}

The data given in Table (4) are modeled on the basis of the initial diameter and weight of the fruiting body. For example, the first cap, which completed its development, had a diameter of $10.9 \mathrm{~cm}$ and a weight of $76 \mathrm{~g}$. The second cap was cut off on the 5th day of development and had a weight of $12 \mathrm{~g}$. The third cap was in the initial stage of growth and weighed $3 \mathrm{~g}$; the growth dynamics of the fruiting bodies is shown in Diagram (2).

The quality of the fruiting bodies largely depends on the rate of water transpiration and its evaporation;fleshy fruiting bodies (weights of 78 and $76 \mathrm{~g}$ ) and bodies with lighter weight $(63 \mathrm{~g})$, dry at different rates. In artificial conditions of keeping after collecting the mushrooms, individuals with a larger mass dry more slowly than those with lighter weight, as evidenced by the data.The dynamics of moisture evaporation by fruiting bodies of various weights is indicated in Diagram(2). 
The effects of temperature and moisture stress

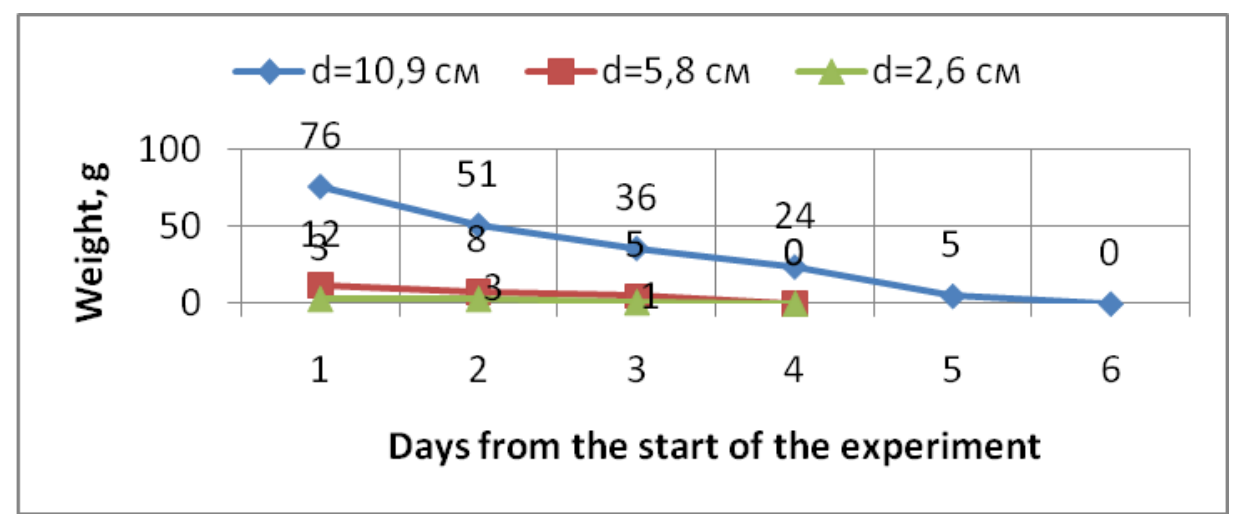

Diagram (2): Dynamics of water evaporation from the fruiting bodies of the oyster mushroom $(\mathrm{g})$.

The studies have shown the need to take into account the rate of evaporation and prevent the decline in the condition of the collected products.

Characteristics of extensive cultivation of oyster mushrooms on cutover areas of tree species:

Plots with stumps were selected in areas where a sparse young growth had already risen consisting mainly of hornbeam and birch (insolation of $40 \%$ from the control of the open area).Since the cutover area was already over ten years old, the upper layer of the stump wood was cut off to the level of healthy wood. The height of the stumps was $40-45 \mathrm{~cm}$. Inoculation was carried out in April 2016.Two methods were used to prepare the stumps for inoculation: undercutting and drilling holes. As recommended (Bysko and Dudka, 1987), for laying grain mycelium, undercuts were made using a wedge method: wedges were cut out from two opposite sides (at the same height) to a depth of $15-20 \mathrm{~cm}$. The mycelium was laid on the lower surface of the stump undercut and on the upper surface of this undercut, and the wedge was again inserted into place. In order to keep moisture in the stumps, plastic bags were put on them which were held until the germination phase was completed in Table (5).

Table (5): Yield of oyster mushrooms on the stumps of tree species (first variant), kg.

\begin{tabular}{|c|c|c|c|}
\hline Species name & First wave & Second wave & Third wave \\
\hline European beech & 0.83 & 1.22 & 1.08 \\
\hline $\begin{array}{c}\text { Common } \\
\text { hornbeam }\end{array}$ & 0.67 & 0.91 & 0.79 \\
\hline Weeping birch & 0.55 & 0.73 & 0.69 \\
\hline
\end{tabular}

Another way was to drill holes. First, as in the previous case, the top layer of the stump, which had been subjected to destruction, was removed. Then a disk $4-5 \mathrm{~cm}$ thick was cut off from the top. On the open surface of the stump, $10 \mathrm{~mm}$ diameter holes were drilled out and grain mycelium was poured into them (1-2 $\mathrm{g}$ of mycelium on the surface of one stump), then the holes were covered with the cut disc in Table (6). 
Popovych et al.

Table (6): Yield of oyster mushrooms on the stumps of tree species (second variant), $\mathrm{kg}$.

\begin{tabular}{|c|c|c|c|}
\hline Species name & First wave (year) & Second wave & Third wave \\
\hline European beech & 1.25 & 1.72 & 1.98 \\
\hline Common hornbeam & 0.75 & 1.12 & 0.90 \\
\hline Weeping birch & 0.63 & 0.82 & 0.75 \\
\hline
\end{tabular}

As you can see, the second variant has a greater effect, because mycelium develops not only on the cut surface, but also on the sides of the stumps.

\section{Peculiarities of extensive cultivation of oyster mushrooms in hollows of broad leaved trees:}

In broadleaved trees, due to the destruction of their wood in the place of mechanical damage, as well as under the influence of saprobic fungi saprotrophs fungi and bacteria and with the participation of ants and birds, hollows are formed that we can often see in suburban forests and urban gardens and parks (Kucheryavyj, 1999). The action of xylophyte fungi was followed by a saprobic mushroom saprophyte mushroom - oyster mushroom.For several years, we conducted research with the planting of oyster mushroom mycelium in the hollows of trees and revealed peculiarities of the fruiting bodiesdevelopment.

Three trees with hollows of approximately the same diameter $(35-40 \mathrm{~cm})$ were selected for the experiment: black poplar, horse chestnut and garden plum tree (about 50 years old). The hollows were $60-70 \mathrm{~cm}$ above the ground. Before the mycelium inoculation (spawning), the hollows were well treated by removing the rotten tissue (to prevent the development of antagonist fungi) and to clean the walls up to living wood. The volume of the hollow is 400$700 \mathrm{~cm}^{3} .150 \mathrm{~g}$ of mycelium was poured on the bottom of a hollow and the hollow was covered with dry leaves.

The development of oyster mushroom was under phenological observations during the 2015-2018 period (Tab.7).

Table (7): Mycelium planting Populus nigra (was done on 27 April 2015).

\begin{tabular}{|c|c|c|c|c|c|c|c|c|c|c|}
\hline \multicolumn{11}{|c|}{ Observation date } \\
\hline \multicolumn{2}{|c|}{1.06 .2015} & \multicolumn{2}{|c|}{ 1.07.2015 } & $\begin{array}{c}1.08 .201 \\
5\end{array}$ & $\begin{array}{c}1.09 .201 \\
5\end{array}$ & \multicolumn{2}{|c|}{1.10 .2015} & \multicolumn{2}{|c|}{1.11 .2015} & $\begin{array}{c}1.12 .201 \\
5\end{array}$ \\
\hline \multicolumn{2}{|c|}{-} & \multicolumn{2}{|c|}{-} & - & - & \multicolumn{2}{|c|}{-} & \multicolumn{2}{|c|}{ - } & - \\
\hline \multicolumn{11}{|c|}{ Observation date } \\
\hline 1.02 & 1.03 & 1.04 & 1.05 & \multirow{3}{*}{$\begin{array}{l}1.06 . \\
2016\end{array}$} & & 1.08 & 1.09 & \multirow{3}{*}{$\begin{array}{c}15.10 \\
2016\end{array}$} & 2.11 & \multirow{3}{*}{$\begin{array}{l}1.12 . \\
2016\end{array}$} \\
\hline 201 & 201 & 201 & 201 & & $\begin{array}{l}1.07 . \\
2016\end{array}$ & 201 & 201 & & 201 & \\
\hline 6 & 6 & 6 & 6 & & & 6 & 6 & & 6 & \\
\hline- & - & - & - & - & - & - & - & + & + & - \\
\hline
\end{tabular}

Note. "-"absence of fruiting bodies; "+" the appearance of fruiting bodies

The first fruiting bodies appeared more than 1.5 year later; the fruiting (first wave) began on 15 October 2016 and ended on 2 July 2016.Over a long period of the development of mycelium hyphae, they germinated from a hollow downward and appeared in a crack which was $20 \mathrm{~cm}$ below the hollow ( $40 \mathrm{~cm}$ above the ground), first in the form of primordia, and subsequently - as fruiting bodies. We found a similar developmental process in forest stands, where germination of hyphae and fruiting bodies spread to the under-hollow part of the trunk. 
The effects of temperature and moisture stress

Planting mycelium in hollows of the horse chestnut and plum trees did not produce any results.

\section{Peculiarities of extensive cultivation of oyster mushrooms using brushwood:}

Since some literature sources refer to the use of brushwood for the cultivation of oyster mushrooms (Bysko and Dudka, 1987), we conducted an experiment in the laboratory of mycology involving a study on destruction of thin branches of the mountain ash by the mycelium of the oyster mushroom. The experiment lasted for 12 months. Under the microscope, the process of destruction of wood was observed (Pl. 1).

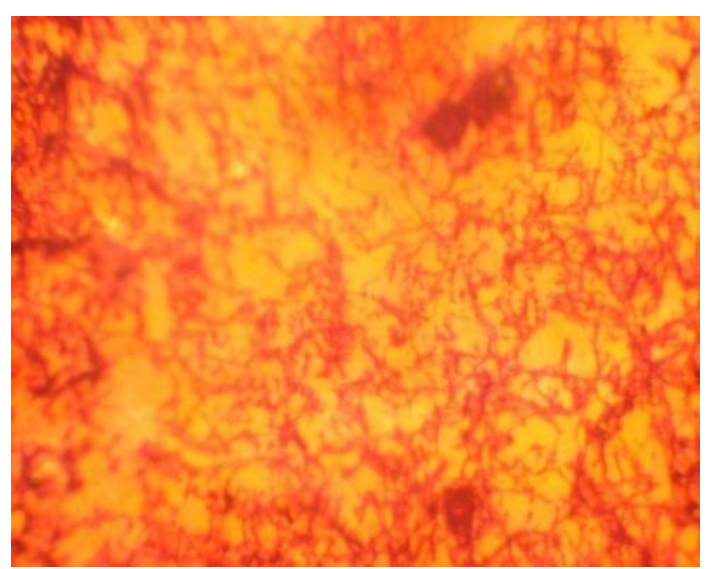

Plate (1): Destruction of wood (dark areas) under the influence of oyster mushroom mycelium.

In April 2017, an experiment began on growing oyster mushrooms on small bundles of brushwood was observed (Pl. 2), of weeping birch. Each bundle had 25 twigs 6-8 mm thick. Before the inoculation, the bundles were steamed in a tub of boiling water. After cooling and after natural drying, each inoculated bundle was put into a plastic bag with holes. Then these bags were suspended on the crossbar in a specially equipped box next to the trial plot with log sections located under the canopy of trees.

Phenological observation began on 7 May 2017, when the average daily temperature rose above $20 \mathrm{C}^{\circ}$; this temperature with certain small fluctuations (air humidity being about $80 \%$ ) was kept on the succeeding days during the period of time until the firstprimordia appeared (29 May 2017).Subsequent observations revealed the first primordia and an insignificant number of fruiting bodies, which after some time came off. 


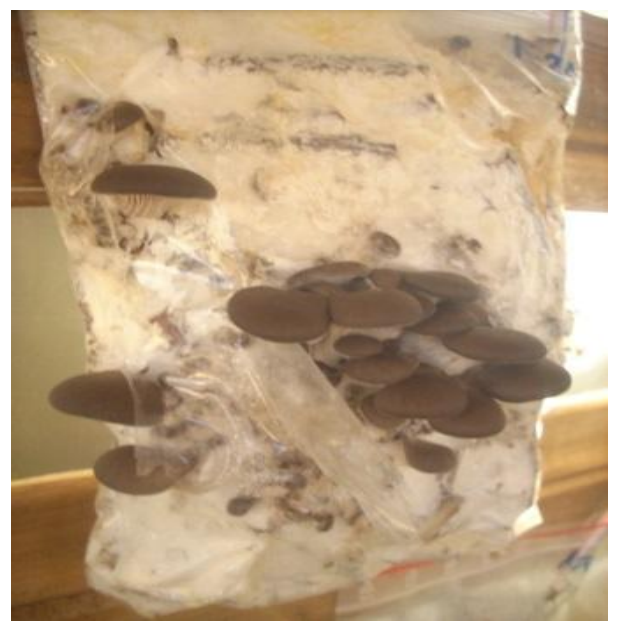

Plate (2): Development of oyster mushrooms on the brushwood substrate.

As mentioned by some authors Bysko and Dudka (1987) and Pavlík (2005); this is due to small, the proportion of cellulose and lignin in the brushwood, which the mushroom should use for destruction and consumption. This being taken into account, shredded twigs and branches should not be used for intensive cultivation of oyster mushrooms.

\section{Peculiarities of extensive cultivation of oyster mushrooms on inoculated log sections in trenches:}

Due to the fact that the period of time between the spring and autumn waves of oyster mushroom fruiting is quite long (almost five months), the log sections are exposed to summer dry air, and therefore, they were regularly watered in the trial plots. This provided the yield of the oyster mushroom during the autumn wave period.

Taking into account the information available in literary sources about the possibility of maintaining the optimum air humidity during the summer period using a trench (Bysko et al., 1983), we carried out an experiment in which the development and fruiting of oyster mushrooms in the trial plot was compared with the development in a trench located under the canopy of a forest stand. The length of the trench is $3 \mathrm{~m}$, the width is $1 \mathrm{~m}$, and the depth is 0.6 $\mathrm{m}$. A thermometer and a psychrometer were hung on a crossbar installed across the trench. For the experiment, aspen $\log$ sections $(10$ pcs $)$ were used which were inoculated simultaneously with the experiments with the eight tree species described above.

The trench microclimate monitoring was conducted from April (the first wave) to October (the second wave) and recorded in a special log book. At the end of the study, the results of the yield of oyster mushrooms in the trial plot (control) and in the trenches were compared. It was found that the biomass of the fruiting bodies of the oyster mushroom grown on the aspen $\log$ sections in the trench was higher than in the control, which indicates the best moisture conditions of the trench (Tab.8). 
The effects of temperature and moisture stress

Table (8): Yield of oyster mushrooms grown on aspen log sections under trench conditions (average air humidity $85 \%$ ) and in the control (73\%).

\begin{tabular}{|c|c|c|}
\hline \multirow{2}{*}{ Log section No. } & trench & Control \\
\cline { 2 - 3 } & fruiting bodies weight, $\mathrm{kg}$ & fruiting bodies weight, $\mathrm{kg}$ \\
\hline 1 & 0.45 & 0.28 \\
\hline 2 & 0.47 & 0.29 \\
\hline 3 & 0.46 & 0.27 \\
\hline 4 & 0.42 & 0.26 \\
\hline 5 & 0.49 & 0.27 \\
\hline 6 & 0.51 & 0.28 \\
\hline 7 & 0.44 & 0.28 \\
\hline 8 & 0.49 & 0.29 \\
\hline 9 & 0.41 & 0.28 \\
\hline 10 & 0.45 & 0.27 \\
\hline Total & 4.59 & 2.77 \\
\hline
\end{tabular}

The relative air humidity of the control plot is lower because of the higher level of insolation and higher air flow; these factors xerophilized the oyster mushroom growth environment - which required moisture for the development of its fruiting bodies. The main prerequisite for a higher yield of oyster mushrooms in the trench was more favorable relative air humidity and the soil moisture than those in the control. This explains the heavier weight of the fruiting bodies that appeared in the summer period.

At the same time, the tested technology for growing oyster mushrooms in the trenches may be of limited use, because, firstly, the trench itself requires shading, secondly, this involves labor-intensive processes of its construction, and thirdly - it may occupy a limited area. The matter is that plots under the canopy of a forest can occupy large areas and do not require large costs for their management.

Peculiarities of extensive cultivation of oyster mushrooms on segments of dry dead wood:

In forest stands, parks and gardens are often found dead standing trees and the wood of which cannot be used in woodworking. Therefore, such dead trees could be used for the production of oyster mushrooms. As in the case of freshly cut wood, for the experiment, we selected three-meter long log segments with a thickness of about $30-35 \mathrm{~cm}$ of two species, beech and aspen; for the best development of the mycelium, the wood pieces were soaked for 3 days in specially made tubs measuring 3 by $2 \mathrm{~m}$.

The purpose of the study was to detect the effect of soil moisture on the development of the oyster mushroom and its fruiting. At the sites under the forest canopy and forest edges, there were installed $10 \mathrm{log}$ sections of aspen and beech dead trees. A month later, the oyster mushroom mycelium grew into the soil to a depth of $15-20 \mathrm{~cm}$, ensuring the supply of water to the fungus. As the studies showed, the first wave of fruiting, observed in SeptemberOctober 2015, revealed the different nature of the activity of the introduction of individuals on the $\log$ sections located in different environmental conditions. The results of oyster mushroom cultivation during the three years of research on log sections of dead wood are given in Table (9).In general, the highest yield is observed in the autumn of the second and third years in the areas located under the broken canopy of trees. 
Popovych et al.

It was found that excessive insolation of the forest edge (twice as high as the under-canopy space), as well as higher xerophilic conditions, adversely affect the growth of mycelium, the development of fruiting bodies and, ultimately, the yield are presented in Table (9).

Table (9): Yield of oyster mushrooms on the log sections of dead wood.

\begin{tabular}{|c|c|c|c|c|c|c|c|}
\hline \multirow{3}{*}{ 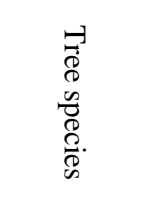 } & \multirow{3}{*}{ 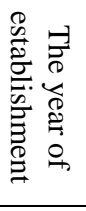 } & \multicolumn{6}{|c|}{ Yield, kg/log section per year } \\
\hline & & \multirow{2}{*}{$\begin{array}{c}2015 \\
\text { Autumn }\end{array}$} & \multicolumn{2}{|c|}{2016} & \multicolumn{2}{|c|}{2017} & \multirow{2}{*}{$\begin{array}{c}\text { In total for } \\
\text { the period } \\
\text { of } \\
\text { observation }\end{array}$} \\
\hline & & & Spring & Autumn & Spring & Autumn & \\
\hline Beech & 2015 & 0.13 & 0.19 & 0.42 & 0.26 & 0.34 & 1.34 \\
\hline Hornbeam & 2015 & 0.12 & 0.16 & 0.38 & 0.18 & 0.20 & 1.04 \\
\hline Lime & 2015 & 0.19 & 0.13 & 0.35 & 0.19 & 0.22 & 1.05 \\
\hline Aspen & 2015 & 0.17 & 0.09 & 0.30 & 0.15 & 0.23 & 0.94 \\
\hline Maple & 2015 & 0.15 & 0.11 & 0.25 & 0.18 & 0.21 & 0.90 \\
\hline Birch & 2015 & 0.17 & 0.09 & 0.19 & 0.07 & 0.18 & 0.70 \\
\hline Poplar & 2015 & 0.16 & 0.10 & 0.25 & 0.12 & 0.14 & 0.77 \\
\hline Rowan tree & 2015 & 0.13 & 0.12 & 0.31 & 0.14 & 0.29 & 0.99 \\
\hline
\end{tabular}

The results of fruiting on fresh-cut wood were higher than on the dead wood which was subjected to soaking.

Confirmed are the findings of mushroom cultivators that grow the oyster mushroom on pieces of wood: the development of mycelium and growth of fruiting bodies requires the necessary amount of water. Therefore, it is important in the process of harvesting wood for $\log$ sections to find out its potential moisture absorption, moisture parameters of freshly cut wood, and also the condition of the dead wood.

Moisture absorption of wood or hygroscopicity of wood is its ability to absorb water vapor from the ambient air. It is characterized by the ratio of the mass of the vapor absorbed by the sample of wood in an absolutely dry state and expressed as a percentage. It consists in monoand polymolecular sorption of vapors by the inner surface of cell walls and their condensation into microcapillaries. The maximum value of moisture absorption of wood is known $30 \%$ at $+20{ }^{\circ} \mathrm{C}$, and it does not depend much on the tree species.

As we have explained in the previous section, the absolute moisture content of wood is essential for the development of mycelium and the growth of the fruiting bodies. Moisture in wood, as mentioned above, is divided into bound (hygroscopic) and free which is located in a cavity cells and intercellular spaces. To characterize the moisture state of wood conditional terms are used: oven-dry wood, that is, the state achieved at a temperature of $100-105^{\circ} \mathrm{C}$. However, wood of dead standing trees contains a small amount of water, which cannot sufficiently ensure the development of mycelium.

To confirm this data, we conducted a study to find out how much moisture dry dead wood should contain for possible cultivation of oyster mushrooms on it. For the experiment, we selected pieces of dry dead wood with various moisture content in the tissues: these were 
The effects of temperature and moisture stress

pieces of European beech and aspen. The measurements of absolute moisture content and inoculation were started with an index of $20 \%$ (air-dry state), continuing at intervals of $100 \%$, $120 \%, 200 \%$ in Table (10).

Table (10): Absolute moisture content of wood segments and the development of oyster mushrooms.

\begin{tabular}{|c|c|c|c|}
\hline \multirow{2}{*}{ Species name } & \multicolumn{3}{|c|}{ Absolute moisture content of wood, \%, the beginning of fruiting } \\
\cline { 2 - 4 } & 100 & 120 & 200 \\
\hline European beech & - & + & + \\
\hline Aspen & - & \pm & + \\
\hline
\end{tabular}

Note: (-) no fruiting; ( \pm ) the beginning of fruiting, low abundance; (++) high abundance

Fruiting on the beech log sections started at an absolute wood moisture content of $100 \%$, but it was weak, and at a moisture content of $120 \%$ - was abundant (18-22 pieces per log section).Aspen, which has a larger cellular structure and larger intercellular spaces and less water filling, demanded more moisture saturation and was characterized by weak fruiting at a $120 \%$ absolute moisture content, andat $200 \%$ - abundant fruiting. These experiments confirm the need to water-soak dry dead wood which in a three-day period absorbs such an amount of moisture that is close to natural, but this process requires regular monitoring, especially before inoculation. The collected data on the yield of oyster mushrooms on the log sections of freshly cut wood and log sections of dry dead wood found a pattern: the larger the diameter of the log section, the larger the size of the fruiting bodies.

Wood, as discussed above, contains cellulose and lignin - the main components of biological decomposition in the process of carbon cycle in nature. Wood contains $40-50 \%$ of cellulose (the lower limit corresponds to broadleaved- , the upper - to coniferous species). At the same time, broadleaved species contain $20-30 \%$ of lignin, and conifers - up to $52 \%$.It is these complex natural organic compounds that are the object of decomposition by xylophytes, and after destruction - by saprotrophs. It is clear that the larger the diameter of the trunk and the more advanced age of the tree, the more it has accumulated cellulose and lignin are presented in Table (11).

Table (11): Dependence of the fruiting body size (diameter of the cap) on the thickness of the beech log section (freshly cut wood).

\begin{tabular}{|c|c|c|c|c|c|c|c|c|}
\hline \multirow{2}{*}{$\begin{array}{c}\text { Date of } \\
\text { measurement }\end{array}$} & \multicolumn{8}{|c|}{ Diameter of the cap, cm } \\
\hline & 52 & 45 & 39 & 35 & 31 & 25 & 20 & 16 \\
\hline October 2015 & 13.3 & 12.6 & 12.1 & 11.8 & 10.9 & 8.7 & 6.4 & 5.5 \\
\hline $\begin{array}{c}\text { November } \\
2016\end{array}$ & 14.0 & 13.6 & 12.9 & 12.0 & 10.7 & 9.1 & 5.9 & 5.2 \\
\hline October 2017 & 13.6 & 12.9 & 12.6 & 12.4 & 11.3 & 9.7 & 6.7 & 5.3 \\
\hline Total & 40.9 & 39.1 & 37.6 & 36.2 & 32.7 & 26.5 & 19.0 & 16.4 \\
\hline Average index & 13.6 & 13.03 & 12.5 & 12.0 & 10.9 & 8.5 & 6.3 & 5.4 \\
\hline
\end{tabular}


Popovych et al.

The autumn waves of 2015,2016 , and 2017 showed that the size of the cap is directly dependent on the diameter of the log section; the best suitable are the $\log$ sections $35-50 \mathrm{~cm}$ in thickness.

\section{CONCLUSIONS}

The oyster mushroom fruiting bodies collected in the suburban forest formed the basis of the experiment on inoculation of different types of substrates. The inoculation of the log sections was carried out in the cellar with a relative air humidity of $85 \%$, the process of overgrowing lasted from 2 to 3 months. Mycelium-overgrown log sections were installed in the trial plots at a distance of $30 \mathrm{~cm}$ apart.Edaphic-climatic factors of various types of spaces closed and open - were taken into consideration.The productivity of the oyster mushroom depends on the tree species and the absolute moisture content of the wood, as well as on the thickness of the log section.

The beginning of the development and growth of fruiting bodies is associated with a stress temperature factor (the AET is $3.9-4.8^{\circ} \mathrm{C}$ ), and the general index of the entire period of the development ranges from $5.4-16.2^{\circ} \mathrm{C}$. The duration of the growth of the fruiting body cap lasts, on average, 12 days.

The cultivation of oyster mushrooms on the stumps of hornbeam-oak cutover areas, as well as with the use of trenches under the canopy of stands of 0.5 density, proved to be successful. The inoculation of thin branches of brushwood turned out to be ineffective, as the growth of the mushroom fruiting bodies ceased at the stage of primordial formation.

\section{LETRATURE CITED}

Bulat, A. G. 2009. Scientific prerequisites for the use of antagonistic fungi in the prevention and protection of pine stands from root sponge damage. Bulletin of KhNAU, Forestry, 1: 217-220.

Bysko, N. A., Buteyko, L. F., Dudka, I. A. and Shevchenko, S.V. 1982. Cultivation of the fungus Pleurotus ostreatus Kumm. By extensive way in Lviv region. Plant Resources, 18 (3): 407-411.

Bysko, N. A., Bukhalo, A. S. and Wasser, S. P. 1983. Higher edible basidiomycetes in superficial and deep culture. Naukova dumka, Kyev, 312 pp.

Bysko, N. A. and Dudka, I. A. 1987. Biology of cultivation of edible mushrooms of the genus Oyster mushroom. Naukova dumka, Kyev, 148 pp.

Černý, A. 1989. Parazitické dřevokazné houby, Ministerstvo lesnictví a vodního hospodářství a dřevozpracujícího průmyslu ČSR ve Státním zemědělském nakladatelství v Praze ve sbírce Lesnictví, myslivost a vodní hospodářství, Praha, 273 pp. (In Czech).

Kucheryavyj, V.P. 1999. Urboecology. Svit, Lviv, 360 pp.

Kucheryavyj, V.P. 2010. General ecology. Svit, Lviv, 520 pp. 
The effects of temperature and moisture stress

Kucheryavyj, V. P., Popovych, V. V. and Les, M. M. 2016. Oyster mushroom (Pleurotus ostreatus) in the system of biocoenotic relations with pests. Scientific Bulletin of $U N F U, 26$ (8): 129-133. (In Ukrainian)

Luthardt, W. 1968. Speisepilze, die auf Holz wohnen. Steinach. Thur.: Vogel, Aritz, 357 pp. (In German).

Pakhomova, O. E. 2014. Ecology. Folio, Kharkiv, 666 pp.

Pasternak, V. P. and Yarotsky, V. Y. 2010. Stocks and dynamics of dead wood in the forests of northeastern Ukraine. Scientific Bulletin of the National University of Bioresources and Nature Management of Ukraine, 152 (2): 93-100. Available at: http://elibrary.nubip.edu.ua/8888/1

Pavlík, M. 2005.Growing of Pleurotus ostreatus on woods of various deciduous trees. Acta Edulis Fungi, 12: 306-312.

Pavlik, M. and Pavlik, Š. 2013. Wood decomposition activity of oyster mushroom (Pleurotus ostreatus) isolate in situ. Journal of Forest Science, 59 (1): 28-33.

Piškur, B., Bajc, M., Robek, R., Humar, M., Sinjur, I., Kadunc, A., Oven, P., Rep, G., Al Sayegh, P. S., Kraigher, H., Jurc, D. and Pohleven, F. 2011. Influence of Pleurotus ostreatus inoculation on wood degradation and fungal colonization. Bioresource Technology, 102: 10611-10617.

Popovych, V. V., Les, M. M. 2014. Destruction of wood waste under the influence of Pleurotus ostreatus mycelium. Bulletin of the Lviv State University of Life Safety, 9: 160-165. Available at: http://nbuv.gov.ua/UJRN/Vldubzh_2014_9_23

Veretenikov, A. V. 1987. Plant physiology with the basics of biochemistry. Voronezh University Press, Voronezh, 256 pp. 
oyster ثيرات الاجهاد الحراري والمحتوى الرطوبي في الاكثار الموسع لفطر المحار mushroom

فاسيل بوبوفيتش * ميخايلو ليس ** تاراس شوبلات * بافلو بوساك *

ميخائيل فيتاك ** وناتاليا بوبوفيتش مئش

* قسم السلامة البيئية، جامعة لفيف الحكومية لسلامة الحياة، لفيف، أوكرانيا.

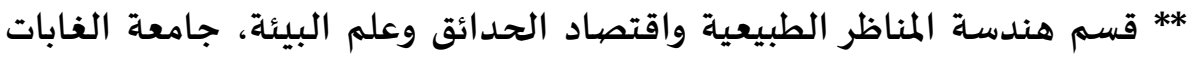
الوطنية الأوكرانية، لفيف، أوكرانيا.

ق**** قسم التخصصيات القانونية والإدارية، جامعة لفيف الحروانيان الحكومية للشؤون الداخلية، لفيف، أوكرانيا.

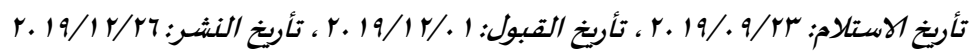
الملخص

Oؤدي فطر المحار Oyster mushroom (Pleurotus ostreatus (Jacq. Ex Fr.) Kumm دورا مهما في تحطيم الخشب الميت الذي يعد وسطا رئيسا لأستيطان احياء مختلفة

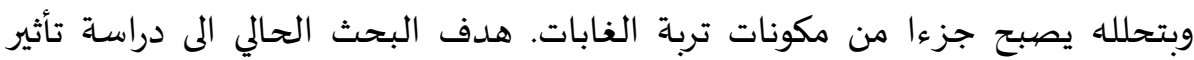

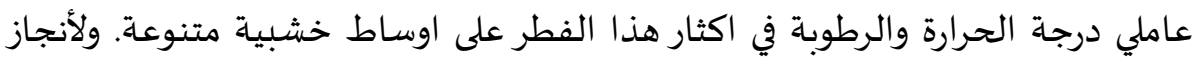

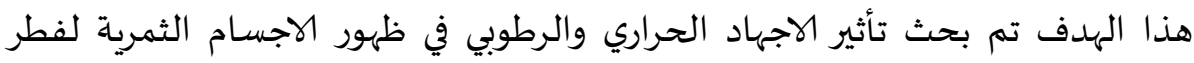

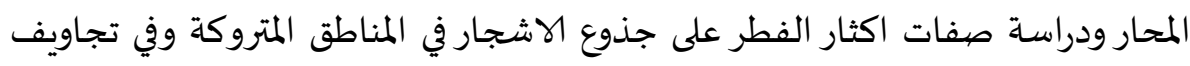

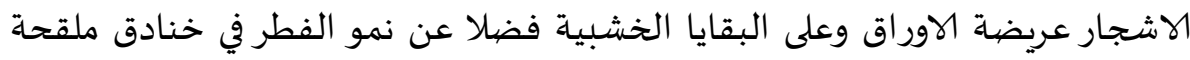

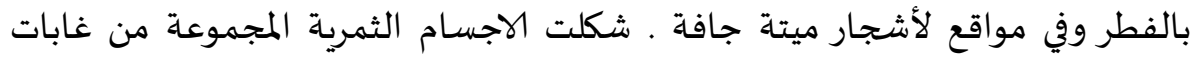

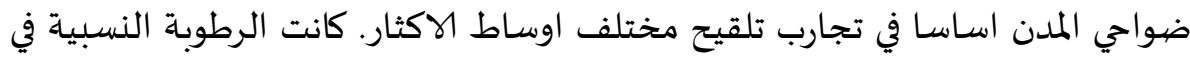

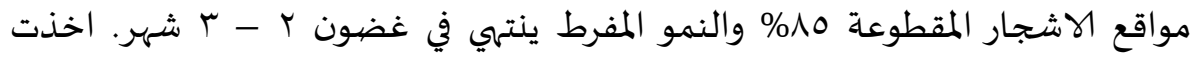

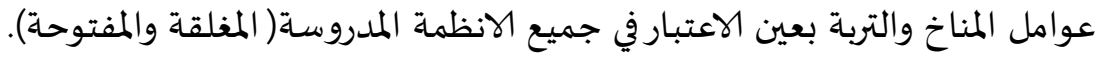

